\title{
Cloning, Characterization, and Functional Studies of a Nonintegrin Platelet Receptor for Type I Collagen
}

\author{
Thomas M. Chiang, ${ }^{\ddagger}$ Augustinus Rinaldy, ${ }^{\ddagger}$ and Andrew H. Kang ${ }^{\star \ddagger \S}$ \\ $*$ Veterans Administration Medical Center, Memphis, Tennessee 38104; and ${ }^{\ddagger}$ Department of Medicine and ${ }^{\S}$ Department of Biochemistry, \\ University of Tennessee at Memphis, Memphis, Tennessee 38104
}

\begin{abstract}
A cDNA (1.6 kb) encoding a platelet protein receptor that binds type I collagen has been isolated from a human bone marrow cDNA library by using a degenerate oligonucleotide probe derived from the amino acid sequence of a $\mathrm{CNBr}$ fragment of the purified receptor. Computer search revealed that this cDNA represents the coding sequence of a unique protein. Using the prokaryotic expression system pKK 223-3-65 cDNA, a 54-kD recombinant protein was obtained and purified to apparent homogeneity. In an eukaryotic expression vector (pcDNA3-65 $\mathrm{cDNA}$ ), a 65-kD protein was identified that was recognized by monoclonal anti-65 $\mathrm{kD}$ antibody (anti-65m). The recombinant protein binds to type I, but not to type III collagen by affinity column chromatography. The binding of the recombinant protein to type I collagen-coated Petri dishes is inhibited by anti-65m in a dose-dependent manner. The pcDNA3-65 cDNA-transfected nonadherent $T$ cells express the protein, allowing them to attach to a type I collagen matrix, and are inhibited by anti-65m in a dose-dependent manner. Like the receptor protein purified from platelet membranes, the recombinant protein inhibits type I collagen-induced platelet aggregation and the adhesion of $\left[{ }^{14} \mathrm{C}\right]$ serotonin-labeled platelets to type I collagen in a dose-dependent manner. The recombinant protein neither binds to type III collagen-coated Petri dishes nor inhibits type III collagen and ADP-induced platelet aggregation, indicating specificity for type I collagen. (J. Clin. Invest. 1997. 100:514-521.) Key words: platelet aggregation - platelet aggregation inhibitor • collagen $\bullet$ receptor
\end{abstract}

\section{Introduction}

After injury to the blood vessel wall, circulating platelets adhere to the underlying connective tissue, spread, become activated, and aggregate, forming a hemostatic plug. Although several components of the connective tissue (such as fibronectin, laminin, thrombospondin, and von Willebrand factor) have been shown to be active in platelet adhesion, collagen is thought to be the most thrombogenic matrix molecule in that in addition to adhesion, it also causes activation and aggregation of platelets. Platelet adhesion and activation are also cru-

Address correspondence to Thomas M. Chiang, Research Service, Veterans Administration Medical Center, 1030 Jefferson Ave., Memphis, TN 38104. Phone: 901-523-8990 ext. 7608; FAX: 901-577-7273; E-mail: tchiang@utmem2.utmen.edu

Received for publication 26 February 1997 and accepted in revised form 2 May 1997.

The Journal of Clinical Investigation

Volume 100, Number 3, August 1997, 514-521

http://www.jci.org cial for pathologic thrombosis where atherosclerotic processes lead to exposure of subendothelial connective tissue to the flowing blood. Thus, an understanding of the mechanisms by which platelets adhere to collagen may be useful in devising therapeutic strategies to intervene in thrombosis.

Adhesion of platelets to collagen is clearly complex. Many platelet membrane proteins have been proposed as mediators of platelet adhesion to collagen. Several of these belong to the integrin family; perhaps the most extensively studied and characterized is the $\alpha 2 \beta 1$ integrin, which is probably identical to the platelet membrane glycoprotein Ia-IIa complex and the very late activation antigen-2 complex $(1,2)$. Other integrins reported as platelet surface receptors for collagen include GPIIb/IIIa and Ia/IIa $(3,4)$, and GPIb-IX $(5,6)$. Other nonintegrin proteins have also been proposed as collagen receptors, including GPIV (7), a $61-\mathrm{kD}$ protein (8), a $62-\mathrm{kD}$ protein called p62 (9), and a $65-\mathrm{kD}$ protein (10), among others (11-19).

Several years ago we isolated, purified, and characterized a nonintegrin platelet membrane glycoprotein (with a $65 \mathrm{kD} M_{\mathrm{r}}$ ) that functioned as a receptor for type I collagen (10). As a further extension of these investigations, in this study we isolated a cDNA clone encoding the $65-\mathrm{kD}$ receptor protein, and have expressed a recombinant protein in both a prokaryotic and eukaryotic expression system. We show that the recombinant protein binds specifically to type I collagen in a dose-dependent manner. When expressed in naturally nonadherent $\mathrm{T}$ cells, the protein renders them adherent to a type I collagencoated matrix that can be inhibited by a specific monoclonal antibody raised against the $65-\mathrm{kD}$ protein (anti-65m) ${ }^{1}$ Finally, the purified recombinant protein can inhibit type I collageninduced platelet aggregation and the release of ATP in a manner identical to the native $65-\mathrm{kD}$ protein isolated from platelets as previously described by us.

\section{Methods}

Cloning of the platelet receptor for type I collagen. The platelet receptor protein $\left(65 \mathrm{kD} M_{\mathrm{r}}\right)$ was purified from isolated human platelet membranes as previously described (10), and was digested with $\mathrm{CNBr}$ as follows: $10 \mathrm{mg}$ of purified protein was dissolved in $4 \mathrm{ml}$ of $75 \%$ formic acid, and was saturated with $\mathrm{N}_{2}$ for 10 min before $0.5 \mathrm{~g}$ cyanogen bromide was added. The test tube was sealed and incubated at $40^{\circ} \mathrm{C}$ for $4 \mathrm{~h}$. At the end of incubation, the sample was diluted to $50 \mathrm{ml}$ with cold distilled water, and was frozen and lyophilized. The lyophilized material was dissolved in SDS-PAGE sample buffer, and was subjected to $15 \%$ SDS-PAGE (20). The protein was then electrophoretically transferred onto a polyvinylidene difluoride membrane $(6 \mathrm{~h}$ at $\left.4^{\circ} \mathrm{C}\right)(21)$ followed by Amido black staining before destaining with

1. Abbreviations used in this paper: anti- $65 \mathrm{~m}$, monoclonal anti- $65 \mathrm{kD}$ antibody; anti-47p, anti-type III collagen receptor antibody; CEM, nonadherent T lymphoma cell line; $\mathrm{CHO}$, Chinese hamster ovary; LB, liquid broth; PRP, platelet-rich plasma; TBS, $20 \mathrm{mM}$ Tris, $500 \mathrm{mM}$ $\mathrm{NaCl}$, Tween 20 (0.25 ml/liter), $\mathrm{pH} 7.4$. 
distilled water. The distinct bands were cut individually and frozen at $-20^{\circ} \mathrm{C}$, and were sequenced with a vapor phase protein sequenator (Protein Core Laboratory, Veterans Administration Medical Center, Memphis, TN).

The amino-terminal sequence (14 amino acids residues) of a large CNBr fragment $\left(25 \mathrm{kD} M_{\mathrm{r}}\right)$ was determined and used to design degenerate oligonucleotide probes according to the method developed by Lathe (22). Probe 1 (21 mers) is as follows: $5^{\prime}-\mathrm{GA}(\mathrm{T} / \mathrm{C}) \mathrm{AT}(\mathrm{C} / \mathrm{A} /$ T) $\mathrm{CC}(\mathrm{G} / \mathrm{A} / \mathrm{T} / \mathrm{C})(\mathrm{T} / \mathrm{C}) \mathrm{T}(\mathrm{G} / \mathrm{A} / \mathrm{T} / \mathrm{C}) \mathrm{GA}(\mathrm{A} / \mathrm{G}) \mathrm{GG}(\mathrm{G} / \mathrm{A} / \mathrm{T} / \mathrm{C}) \mathrm{TA}(\mathrm{T} /$ C)-3' derived from amino acid sequence D-I-P-L-E-G-Y. Probe 2 (21 mers) is as follows: $5^{\prime}-\mathrm{CC}(\mathrm{G} / \mathrm{A} / \mathrm{T} / \mathrm{C}) \mathrm{GT}(\mathrm{G} / \mathrm{A} / \mathrm{T} / \mathrm{C}) \mathrm{GG}(\mathrm{G} / \mathrm{A} / \mathrm{T} / \mathrm{C})$ $\mathrm{AC}(\mathrm{G} / \mathrm{A} / \mathrm{T} / \mathrm{C}) \mathrm{GA}(\mathrm{A} / \mathrm{G})(\mathrm{T} / \mathrm{C}) \mathrm{T}(\mathrm{G} / \mathrm{A} / \mathrm{T} / \mathrm{C}) \mathrm{AC}(\mathrm{G} / \mathrm{A} / \mathrm{T} / \mathrm{C})-3^{\prime}$ derived from amino acid sequence P-V-G-T-E-L-T.

The degenerate oligonucleotides were end-labeled with T4 polynucleotide kinase using $\left[{ }^{32} \mathrm{PO}_{4}\right]-\gamma$-ATP (Amersham Corp., Arlington Heights, IL) and purified through a G-25 column (Stratagene Inc., La Jolla, CA). These end-labeled probes were used to screen the human bone marrow cDNA library (CLONTECH, Palo Alto, CA). Two positive clones were isolated from the screening of $10^{6}$ plaques.

Initial screening of a human bone marrow $\lambda \mathrm{gt} 11 \mathrm{cDNA}$ library $\left(10^{6}\right.$ plaques) was carried out by using a mixture of both kinased probes. The preliminary positive clones obtained from the initial screening were further screened with each individual probe separately. At the final screening, each oligonucleotide was used separately to assess the positive clones in duplicate. The positive plaque was expanded, and phage DNA was prepared and cut with EcoR1. A 1.6-kb cDNA insert was obtained, gel-purified, and subcloned into pCR II vector (TA Cloning Kit; Invitrogen Corp., San Diego, CA). Plasmid DNA preparation was subjected to restriction enzyme digestion, and was analyzed on agarose gel electrophoresis (data not shown). An intact 1.6-kb full length cDNA insert was recovered by EcoRI digestion, and two fragments were identified by PstI (4.5 and 1 $\mathrm{kb}$ ), whereas the pCR II-cDNA construct was only linearized with ScaI (5.5 kb).

The cDNA was ligated into a pKK 223-3 prokaryotic expression vector (Pharmacia Biotechnology, Piscataway, NJ), heat-shocked into Escherichia coli (JM 105), and grown on liquid broth (LB) agar. Single colonies were picked and regrown in LB with streptomycin and ampicillin in the presence of $1 \mathrm{mM}$ isopropylthio- $\beta$-D-galactoside (Gibco Laboratories, Grand Island, NY) overnight. Protein from cell extracts was analyzed by Western analysis using anti-65m (23).

Western blot. Samples were separated by 7.5 or $10 \%$ SDS-PAGE (20), and were electrophoretically transferred onto a nitrocellulose sheet (23-25), followed by treatment with $3 \%$ dried milk in $20 \mathrm{mM}$ Tris, $500 \mathrm{mM} \mathrm{NaCl}$, Tween 20 (0.25 ml/liter vol/vol), pH 7.4 (TBS) to eliminate nonspecific binding. The nitrocellulose sheet was then washed three times with TBS and incubated with anti-65m $(2 \mu \mathrm{g} / \mathrm{ml})$ overnight at $4^{\circ} \mathrm{C}$. After washing three times in TBS, the nitrocellulose sheet was incubated with a second antibody (peroxidase-conjugated goat anti-mouse $\mathrm{IgG}, 1 / 2,000)$ for $3 \mathrm{~h}$ at room temperature. After washing three times with TBS and once with $20 \mathrm{mM}$ Tris-HCl, pH 7.4, the nitrocellulose sheet was developed with enhanced chemiluminescence solution as described by the manufacturer (Amersham Corp.).

Purification of recombinant protein. Transformed bacteria (Escherichia coli, JM 105) containing the pKK 223-3-65 cDNA for the platelet receptor for type I collagen were grown overnight in LB containing ampicillin $(50 \mu \mathrm{g} / \mathrm{ml})$ and streptomycin $(25 \mu \mathrm{g} / \mathrm{ml})$. Cells were harvested and washed with $20 \mathrm{mM}$ phosphate buffer containing 130 $\mathrm{mM} \mathrm{NaCl}, \mathrm{pH} 7.4$, followed by resuspension in $50 \mathrm{mM}$ Tris- $\mathrm{HCl}, \mathrm{pH}$ 7.4, were sonicated for $2 \mathrm{~min}$, and were centrifuged for $20 \mathrm{~min}$ at $15,000 \mathrm{~g}$. The supernatant was subjected to an affinity column using specific anti-65m coupled to Sepharose 4B (23). The column was equilibrated and washed with $20 \mathrm{mM}$ phosphate, $130 \mathrm{mM} \mathrm{NaCl}, \mathrm{pH}$ 7.4 (PBS). The bound protein was eluted with $0.2 \mathrm{M}$ glycine, $\mathrm{pH} 3.5$, neutralized with $1 \mathrm{M}$ Tris base, and dialyzed against distilled water (three changes) at $4^{\circ} \mathrm{C}$. The dialyzed pool fraction was lyophilized, reconstituted in PBS, and redialyzed against the same buffer. The protein concentration was determined by the method of Lowry et al. (26).
Preparation of platelet-rich plasma (PRP), platelet aggregometry, and washed platelets. PRP was prepared from healthy volunteer donors as described earlier (27). Platelet aggregometry was performed by the turbidimetric method of Born (28) ChronoLog Lumi aggregometer; Chrono-Log Corp., Havertown, PA). Washed platelets were prepared by mixing equal volumes of PRP and $20 \mathrm{mM}$ Tris, 130 $\mathrm{mM} \mathrm{NaCl}, 1 \mathrm{mM}$ EDTA, pH 7.4 (Tris-NaCl-EDTA) and were centrifuged at $1,000 \mathrm{~g}$ for $5 \mathrm{~min}$. The pellet was washed once with Tris$\mathrm{NaCl}-E D T A$, and was then suspended in the same buffer or autologous platelet-poor plasma at a concentration of 400,000-600,000 platelets $/ \mathrm{mm}^{3}$.

Preparation of type I collagen. Neutral salt-soluble collagen (type I) was extracted from the skins of 3-wk-old white Leghorn chicks according to the method described by Kang et al. (29). Human type I collagen was prepared from placenta in our laboratory, or was purchased from Chrono-Log Corp.

Collagen-coating of microtiter wells. Aliquots of $100 \mu \mathrm{l}$ containing various amounts of type I collagen in phosphate buffer, $\mathrm{pH}$ 7.6, were added into microtiter wells and incubated at $4^{\circ} \mathrm{C}$ overnight. The amount of collagen bound to the wells was determined in parallel experiments using ${ }^{14} \mathrm{C}$-labeled type I collagen. Wells were washed with PBS and incubated with $0.1 \%$ bovine serum albumin $(150 \mu \mathrm{l} /$ well) for $30 \mathrm{~min}$ at room temperature. The wells were washed with PBS again before the addition of ${ }^{51} \mathrm{Cr}$-labeled transfected cells. At the end of incubation, the wells were washed five times with PBS. The radioactivity recovered from each well after solubilization with 5\% SDS was detected by scintillation counting in the presence of $10 \mathrm{ml}$ ScintiVerse BD (Fisher Scientific Co., Pittsburgh, PA).

Microtiter cell adhesion assay. A nonadherent $\mathrm{T}$ lymphoma cell line $\left(\mathrm{CEM}\right.$ cells) $\left(5 \times 10^{9}\right)$ was electroporated in the presence of pcDNA3-65 cDNA $(200 \mu \mathrm{g})$, and was grown on type I collagencoated Petri dishes at $37^{\circ} \mathrm{C}$ for $3 \mathrm{~d}$ in a $5 \% \mathrm{CO}_{2}$ incubator. Adherent cells were detached with a buffer solution containing trypsin-EDTA, and were transferred to a tube containing medium with $15 \%$ FCS and soybean trypsin inhibitor $(1 \mathrm{mg} / \mathrm{ml})$. This cell suspension was centrifuged, and the cell pellets were resuspended in growing medium for $4 \mathrm{~h}$ in non-collagen-coated Petri dishes. At the end of incubation, cells were harvested and washed with growing medium without FCS and antibiotics. Cell suspensions (adjusted to $2 \times 10^{7} / \mathrm{ml}$ ) in growing medium containing $0.1 \%$ (wt/vol) bovine serum albumin and $200 \mu \mathrm{Ci} / \mathrm{ml}$ of sodium $\left[{ }^{51} \mathrm{Cr}\right]$ chromate (Amersham Corp.) were incubated at $37^{\circ} \mathrm{C}$ for $30 \mathrm{~min}$ in a shaking water bath. After incubation, the cells were repeatedly washed until free $\left[{ }^{51} \mathrm{Cr}\right]$ in the supernatant was at a minimum $(30,31)$. The washed and labeled cells were suspended in PBS $\left(10^{5} / \mathrm{ml}\right)$, applied to collagen-coated microtiter wells, and incubated for another $30 \mathrm{~min}$. Then the wells were washed with PBS $(150 \mu \mathrm{l})$ seven times. The attached cells were solubilized with $2 \%$ SDS, and the radioactivity recovered was assessed by gamma counting. The specificity of adhesion of cDNA-transfected cells to type I collagencoated wells was tested using specific antibodies to the receptor protein as specified (see Table III).

\section{Results}

Amino acid sequence of isolated CNBr fragments of the $65-k D$ protein. The purified $65-\mathrm{kD}$ protein was digested with $\mathrm{CNBr}$, and two large fragments $\left(25\right.$ and $\left.6 \mathrm{kD} M_{\mathrm{r}}\right)$ were isolated by SDS-PAGE. The amino-terminal sequence of the $25-\mathrm{kD}$ $\mathrm{CNBr}$ peptide was determined by Edman degradation in an automated peptide sequencer. The sequence of D-I-P-L-E-GY-P-V-G-T-E-L-T was obtained. A search of computer databases (gene and protein) (National Center for Biotechnology Information, National Institutes of Health, Bethesda, MD) failed to yield a match to any known protein.

Establishment of the primary structure of the $65-\mathrm{kD}$ protein. The pKK 223-3-65 cDNA was sequenced by using cus- 


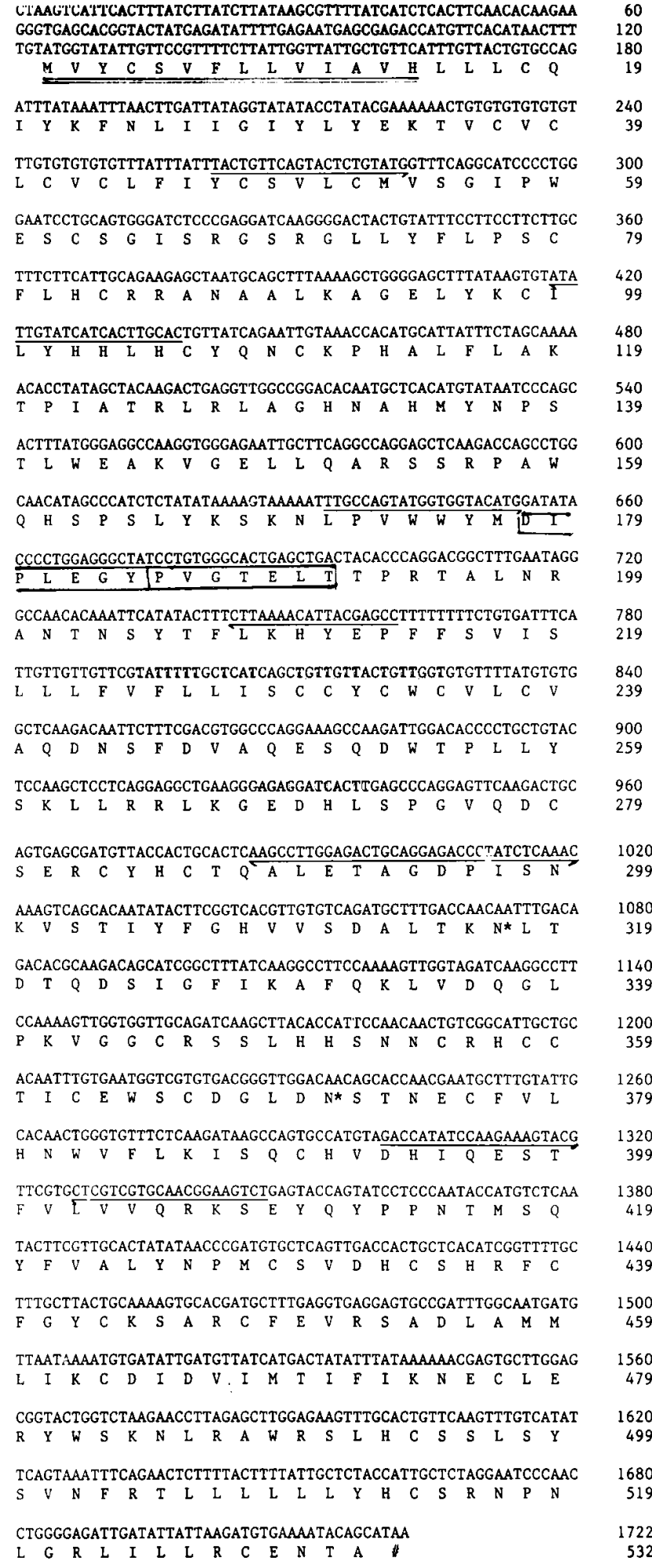

Figure 1. Nucleotide sequence and the deduced amino acid sequence of the cloned cDNA. Custom-designed primers of pKK 223-3 were used to determine the initial nucleotide sequence of the cloned cDNA by chain termination reaction. Other primers (underlined with arrow to indicate the direction of the sequence) were made according to the sequenced portion of the cDNA. The deduced amino acid sequence was determined with a computer program (DNA Strider; Pasteur Institute, Paris, France). The sequence that is identical to the degenerate probes is boxed. The hypothetical signal peptide $(===)$ and tom-designed primers (Fig. 1). The open reading frame represented by 1596 bases of this cDNA starts with the ATG start codon at position 124, and stops with the TAA stop codon at position 1720 of the sequenced nucleotide. The deduced amino acid sequence derived from this open reading frame indicated that the mapping of the $25-\mathrm{kD}$ fragment was between amino acid residues 177 and 417. A computer search of the gene bank, however, did not find any significant homology to our cDNA. A segment of $123 \mathrm{bp}$ from the untranslated region of the $5^{\prime}$-end was also identified. The amino acid sequence corresponding to the degenerate oligonucleotide probes of the isolated $\mathrm{CNBr}$ peptide is shown in boxes. The recombinant protein is $60 \mathrm{kD} M_{\mathrm{r}}$. In addition, two $N$-glycosylation sites were also observed from the deduced amino acid sequence of this receptor. They are located at the amino acid residues 317-319 (N-L-T) and 371-373 (N-S-T) as shown in Fig. 1.

Purification of the recombinant protein. The recombinant protein made in E. coli generated from the pKK 223-3-65 cDNA expression vector was isolated and assessed by using anti- $65 \mathrm{~m}$ in Western blot analysis (Fig. $2 \mathrm{~A}$ ). In this assessment, two colonies expressed a protein that is recognized by the anti- $65 \mathrm{~m}$ (lanes 2 and 4). These two colonies have the same sequence. Protein extracts in lanes 1 and 3 did not react because the cDNA was inserted in the reverse direction as proven in the subsequent sequencing studies (inverted sequence of Fig. 1).

The crude protein from the cell extract was further purified by affinity column chromatography using anti- $65 \mathrm{~m}$ coupled to Sepharose 2B. The degree of purification of the recombinant protein was examined by $7.5 \%$ SDS-PAGE. A single band with a $54 \mathrm{kD} M_{\mathrm{r}}$ was obtained (Fig. 2 B).

The 54-kD $M_{\mathrm{r}}$ purified recombinant protein is somewhat lower than that of the $65-\mathrm{kD}$ protein isolated from platelet membranes. We considered the possibility that the difference in $M_{\mathrm{r}}$ might be due to glycosylation. We therefore treated the purified receptor protein isolated from platelets with endoglycosidase $\mathrm{H}$. The result shown in Fig. $2 C$ indicates that the apparent $65-\mathrm{kD} M_{\mathrm{r}}$ platelet protein (Fig. $2 C$, lane 1 ) was indeed reduced to $54 \mathrm{kD}$ after treatment with endoglycosidase $\mathrm{H}$ (Fig. $2 C$, lane 2). Staining with periodic acid Schiff stain of the control showed a reactive band of $65 \mathrm{kD} M_{\mathrm{r}}$, but the sample treated with endoglycosidase $\mathrm{H}$ did not show a stainable band at $54 \mathrm{kD} M_{\mathrm{r}}$ (Fig. $2 \mathrm{D}$ ). These data strongly support the likelihood that the difference in $M_{\mathrm{r}}$ between these two proteins is due to glycosylation.

In a eukaryotic expression vector (pcDNA3-65 cDNA), a $65-\mathrm{kD}$ protein was indeed expressed in the transfected Chinese hamster ovary $(\mathrm{CHO})$ cells, and this protein product is recognized by the anti-65m (Fig. $3 A$ ). The expression product was observed after 2 d (lane 9 ), significantly increased after day 3 (lane 10) and day 4 (lane 11), but decreased at day 5 (lane 12). Each band was screened with a densitometer. The area density $\left(\mathrm{OD} \times \mathrm{mm}^{2}\right)$ is $1,1.7,2.1,3.9$, and 2.7 for 2-5 d culture (lanes 9-12), respectively. Isolated platelet membranes were used for control (density $=4.9$, lane 13 ). The same time course experiment was performed with inverted cDNA insert transfected $\mathrm{CHO}$ cells (lanes $1-6$ are $0-5 \mathrm{~d}$, respectively). There is no reac-

the glycosylation sites $(*)$ are indicated in the figure. 123 bp of the untranslated region were also shown upstream from the ATG start codon (position 124). The stop codon (TAA) was located at position 1719. 
A
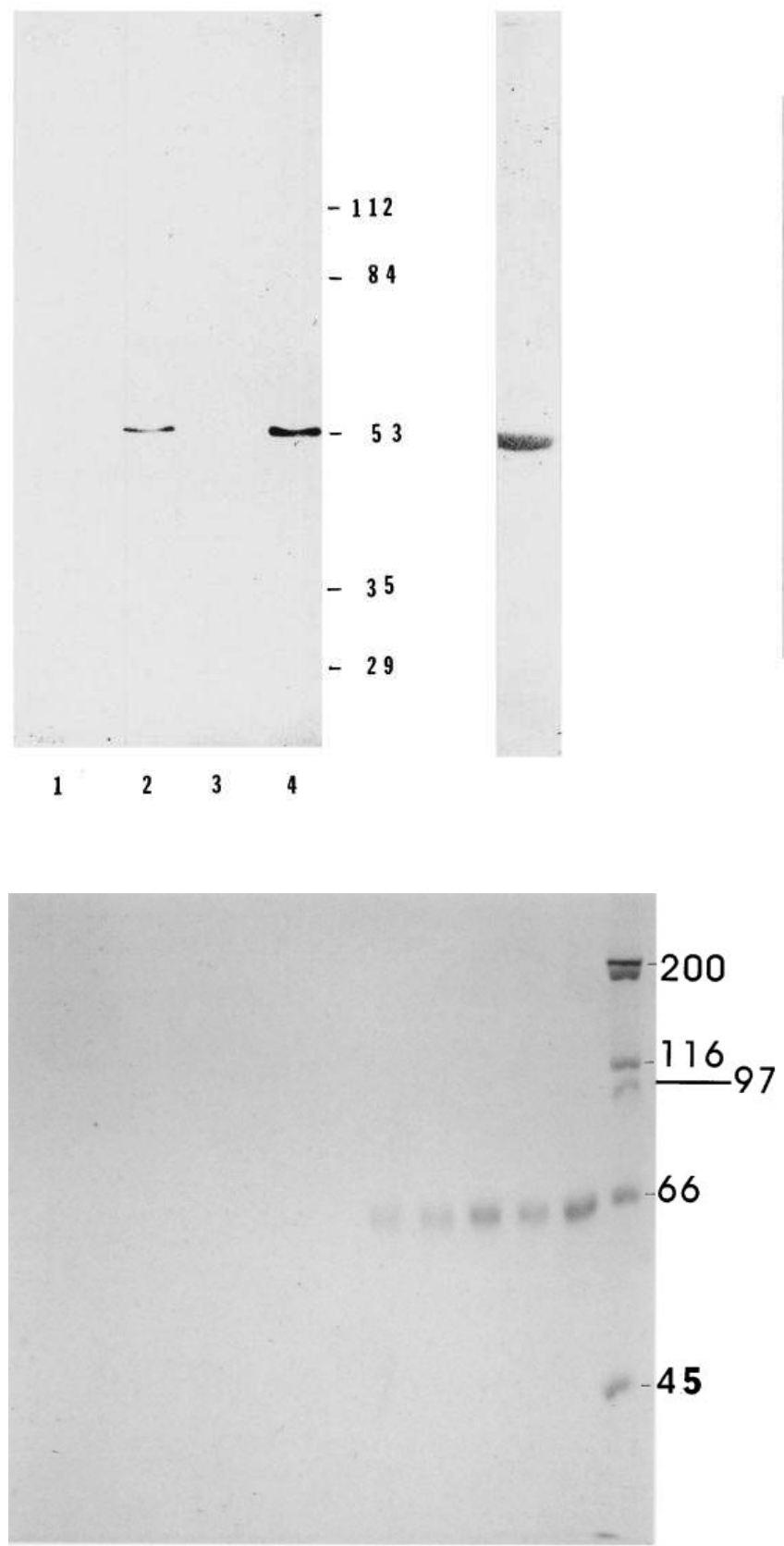

\section{$122 \begin{array}{llllllllll}1 & 3 & 5 & 6 & 7 & 8 & 9 & 10 & 11 & 121314\end{array}$}

Figure 3. Expression of the recombinant protein in $\mathrm{CHO}$ cells. The 65-kD cDNA was ligated into a eukaryotic expression vector (pcDNA3-65 cDNA). The control (inverted sequence, lanes 1-6) and experimental (correct sequence, lanes 7-12) plasmids were electroporated $(10 \mu \mathrm{g})$ into $\mathrm{CHO}$ cells. These cells were grown for $0 \mathrm{~d}$ (lanes 1 and 7), $1 \mathrm{~d}$ (lanes 2 and 8), $2 \mathrm{~d}$ (lanes 3 and 9), $3 \mathrm{~d}$ (lanes 4 and 10), $4 \mathrm{~d}$ (lanes 5 and 11), or $5 \mathrm{~d}$ (lanes 6 and 12) for controls and experiments, respectively. At the end of the experiment, the cells were sonicated in a protease inhibitor buffer, and the protein concentration was determined. An equal amount of protein $(150 \mu \mathrm{g})$ at each time point, and isolated platelet membranes (lane 13), were analyzed by $10 \%$ SDSPAGE, and were electroblotted onto nitrocellulose membrane. The nitrocellulose sheet was Western blotted with the anti-65m, and was developed with ECL solution. Bio-Rad (Hercules, CA) high $M_{\mathrm{r}}$ markers $\left(10^{3}\right)$ are myosin (200), $\beta$-galactosidase (116), phosphorylase B (97), BSA (66), and ovalbumin (45) (lane 14).
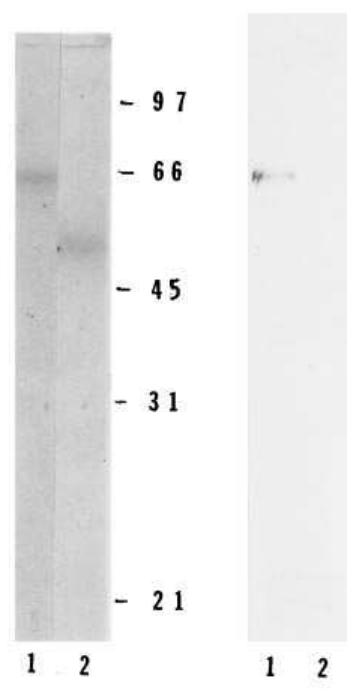

Figure 2. Characterization of protein expressed by pKK 223-3-65 cDNA. $A$ shows Western blot (anti-65m) of four colonies (lanes 2 and 4 with correct inserted cDNA; lanes 1 and 3 with inverted insert; confirmed by cDNA sequence). The prestained $M_{\mathrm{r}}$ markers $\left(10^{3}\right)$ are phosphorylase B (112), BSA (84), ovalbumin (53), carbonic anhydrase (35), and soybean trypsin inhibitor (29). $B$ shows the purified recombinant protein $(10 \mu \mathrm{g})$ analyzed by $7.5 \%$ SDS-PAGE and stained with Coomassie brilliant blue. $C$ and $D$ show the purified platelet $65-\mathrm{kD}$ protein before $(15 \mu \mathrm{g}$, lane 1) and after incubation with endoglycosidase $\mathrm{H}$ (5 U, lane 2). One set of samples was stained with Coomassie brilliant blue $(C)$ and the other set was stained with periodic acid Schiff stain $(D)$.

Markers $\left(10^{3}\right)$ are phosphorylase B (97), BSA (66), ovalbumin (45), bovine carbonic anhydrase (31), and soybean trypsin inhibitor (21). tive band corresponding to $65-\mathrm{kD}$ platelet protein in the inverted cDNA controls.

Binding of the recombinant protein to type I collagen. Several experiments were carried out next to investigate whether the isolated recombinant protein binds to type I collagen specifically. In the first set of experiments, the $\left[{ }^{32} \mathrm{PO}_{4}\right]$-recombinant protein was applied to an affinity column of type I collagenSepharose or type III collagen-Sepharose 2B. As shown in Fig. 4, the radiolabeled recombinant protein bound to type I collagen-Sepharose 2B (Fig. 4, $\square-\square$ ) but not to type III collagen-Sepharose-2B (Fig. 4, - $\bullet$ ). The first peak eluting unretarded from the type I-Sepharose $2 \mathrm{~B}$ column represents labeled protein not bound to the affinity column due to overloading.

In additional experiments, varying amounts of the radiolabeled recombinant protein were incubated on type I collagencoated Petri dishes, and the amount of radioactivity bound was measured. As shown in Table I, binding was dependent on the amount of radiolabeled recombinant protein added. Binding was inhibited by a 10-fold excess of unlabeled recombinant protein, indicating that the binding was specific. Moreover, binding could be inhibited in a dose-dependent manner by anti-65m, but not by anti-type III collagen receptor antibody (anti-47p) (32) (Table II). There was no demonstrable binding of the labeled recombinant protein to type III collagen- or fibronectin-coated Petri dishes (data not shown). These data strongly indicate that the recombinant protein binds to type I collagen specifically.

Effect of expression of the recombinant protein in a eukaryotic cell line. To gain an insight into the biologic significance of the $65-\mathrm{kD}$ protein, the effect of expression of the recombinant protein in a nonadherent eukaryotic cell line was studied. CEM cells were transfected with the cDNA construct (pcDNA3-65 cDNA). Cells were then grown on type I collagen-coated Petri dishes $\left(100 \mathrm{~cm}^{2}\right.$ in RPMI medium contain- 


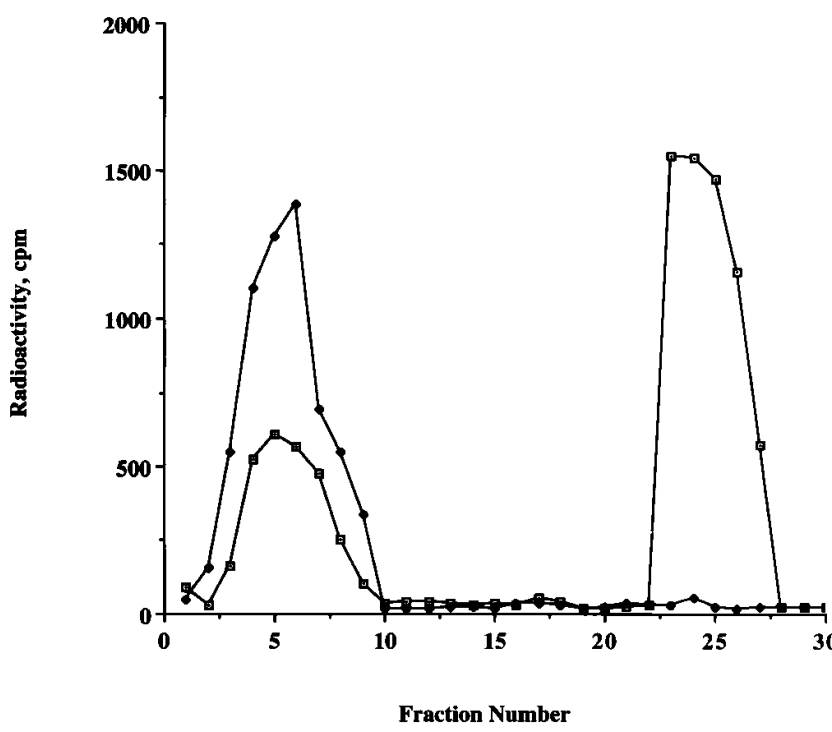

Figure 4. Binding of the isolated recombinant protein to type I collagen-Sepharose 2B column. The purified recombinant protein (3 $\mathrm{mg}$ ) was incubated with cAMP-dependent protein kinase (25 $\mathrm{U})$ and $10 \mu \mathrm{M}\left[{ }^{32} \mathrm{PO}_{4}\right]-\gamma$-ATP for $30 \mathrm{~min}$ and purified on a Sephadex G-25 column. The $\left[{ }^{32} \mathrm{PO}_{4}\right]$-recombinant protein was collected, freeze-dried, redissolved in $20 \mathrm{mM}$ Tris- $\mathrm{HCl}, \mathrm{pH} 7.4$, and dialyzed against the same buffer. One aliquot was applied to type I ( $\square-\square)$, and another aliquot to type III ( $\downarrow)$ collagen affinity column (20-ml gel beads). The columns were washed with $40 \mathrm{ml}$ Tris- $\mathrm{HCl}, \mathrm{pH} 7.4$, followed by $40 \mathrm{ml}$ Tris-HCl, $\mathrm{pH} 7.4$, containing $4 \mathrm{M}$ urea (starting with fraction 20). Fractions were collected, and the radioactivity in each was detected with a counter in the presence of $10 \mathrm{ml}$ ScintiVerse BD (Fisher Scientific Co.). $Y$ axis, radioactivity/fraction; $x$ axis, fraction numbers.

ing pen-strep and $15 \%$ FCS) for $3 \mathrm{~d}$. Two cell populations were obtained; one population of cells attached to type I collagencoated plates, and the second population of cells did not attach but floated in the medium. Both the adherent and nonadher-

\section{Table I. Binding of Recombinant Protein to Type I Collagen}

\begin{tabular}{lc}
\hline$\left[{ }^{32} \mathrm{PO}_{4}\right]$-recombinant protein-added & {$\left[{ }^{32} \mathrm{PO}_{4}\right]$-recombinant protein-bound } \\
\hline & $c p m \pm S D$ \\
$2.5 \mu \mathrm{g}$ & $305 \pm 56$ \\
$5 \mu \mathrm{g}$ & $1202 \pm 871$ \\
$10 \mu \mathrm{g}$ & $1651 \pm 328$ \\
$20 \mu \mathrm{g}$ & $3336 \pm 687$ \\
$20 \mu \mathrm{g}+$ nonlabeled & \\
$\quad$ recombinant protein $(200 \mu \mathrm{g})$ & $451 \pm 72$
\end{tabular}

Biocoat Petri dishes (60 mm; Becton Dickinson, Bedford, MA) were coated with $1 \mathrm{ml}$ type I collagen $(300 \mu \mathrm{g})$ in $120 \mathrm{mM}$ phosphate buffer, $\mathrm{pH} 7.6$, at $4^{\circ} \mathrm{C}$ overnight. The wells were washed with PBS three times. Various amounts of $\left.{ }^{32} \mathrm{PO}_{4}\right]$-recombinant protein $(1 \mathrm{ml})$ were added to the dishes, followed by incubation at room temperature for $30 \mathrm{~min}$. At the end of incubation, each dish was washed with PBS $(2 \mathrm{ml})$ five times. The bound recombinant protein was detached from the dish by two washes with a solution of $2 \%$ SDS-PBS $(1 \mathrm{ml}$ each). The washes were combined in a vial, and the radioactivity in each vial was assessed with a scintillation counter in the presence of $10 \mathrm{ml}$ ScintiVerse BD (Fisher Scientific Co.). Data are expressed as mean \pm SD of triplicate experiment.
Table II. Effect of Anti-65m and Anti-47p on Binding of Labeled Recombinant Protein to Type I Collagen-coated Petri Dishes

\begin{tabular}{ccc}
\hline $\mathrm{IgG}$ & Bound $\left[{ }^{32} \mathrm{PO}_{4}\right]$-recombinant & protein $(\mathrm{cpm} \pm \mathrm{SD})$ \\
\hline$\mu g$ & Anti- $65 m^{*}$ & Anti-47p \\
0 & $1630 \pm 126$ & $1630 \pm 126$ \\
1 & $1043 \pm 113$ & $1545 \pm 174$ \\
5 & $485 \pm 184$ & $1651 \pm 45$ \\
10 & $293 \pm 97$ & $1687 \pm 85$ \\
20 & $137 \pm 78$ & $1648 \pm 117$ \\
\hline
\end{tabular}

Various amounts of anti- $65 \mathrm{~m}$ and anti- $47 \mathrm{p}$ were added to the test tubes containing $10 \mu \mathrm{g}$ of $\left[{ }^{32} \mathrm{PO}_{4}\right]$-recombinant protein in a final volume of 1 $\mathrm{ml}$, and were incubated at room temperature for $30 \mathrm{~min}$. The incubated materials were then transferred to PBS-washed Biocoat Petri dishes (60 $\mathrm{mm}$ ) (Becton Dickinson Labware, Bedford, MA) that were coated with type I collagen and incubated for another $30 \mathrm{~min}$. At the end of incubation, the Petri dishes were washed with PBS, and the radioactivity in each dish was assessed as described in Table I. Data are expressed as mean \pm SD of triplicate experiments. ${ }^{*}$ Anti- $65 \mathrm{~m}$ is monoclonal $\mathrm{IgG}$ raised against type I collagen receptor $(65 \mathrm{kD})(23) .{ }^{\ddagger} \mathrm{Anti}-47 \mathrm{p}$ is polyclonal IgG raised against type III collagen receptor (47 kD) (32).

ent cells were collected separately, lysed by sonication, and analyzed by Western blot as shown in Fig. 5. Both the adherent cells (lane 3) and platelet membranes (used as positive control, lane 4$)$ showed a band $(65 \mathrm{kD})$ that is recognized by the anti$65 \mathrm{~m}$. By contrast, neither the vector-transfected cells (used as

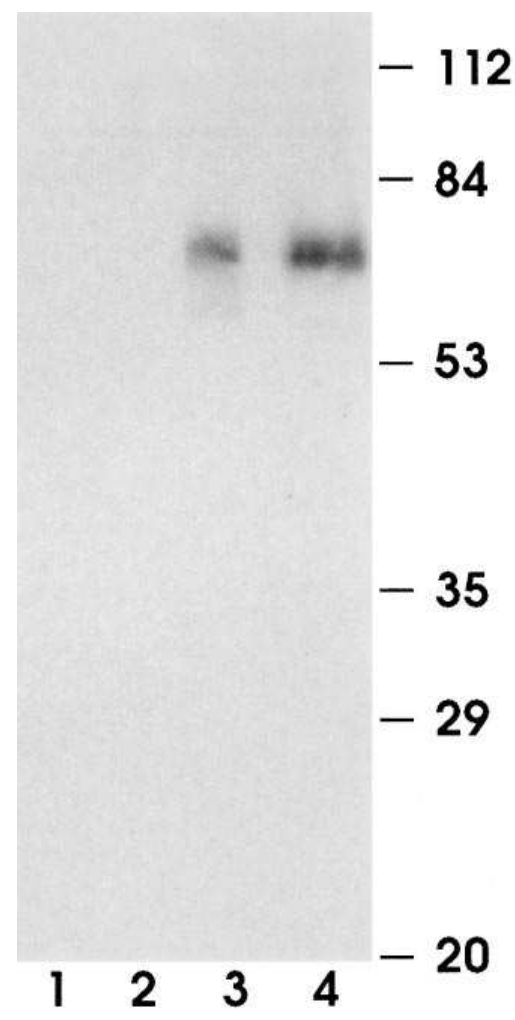

Figure 5. Expression of the recombinant protein in nonadherent eukaryotic cells. The pcDNA3-65 cDNA was electroporated $(20 \mu \mathrm{g})$ into CEM cells. The transfected cells were grown on type I collagen-coated Petri dishes $\left(100 \mathrm{~cm}^{2}\right.$ in RPMI medium containing pen-strep and $15 \%$ FCS) for $3 \mathrm{~d}$. The vector-transfected cells (lane 1) and transfected, nonadherent cells (lane 2) were collected from the suspension. The Petri dishes were then washed three times with PBS (10 ml each), and the adherent cells (lane $3)$ were detached from the Petri dishes with a rubber policeman. Western blot was performed with anti-65m and developed with ECL solution. The isolated platelet membranes (lane 4 ) served as a positive control. The prestained $M_{\mathrm{r}}$ markers are the same as Fig. $2 A$. 


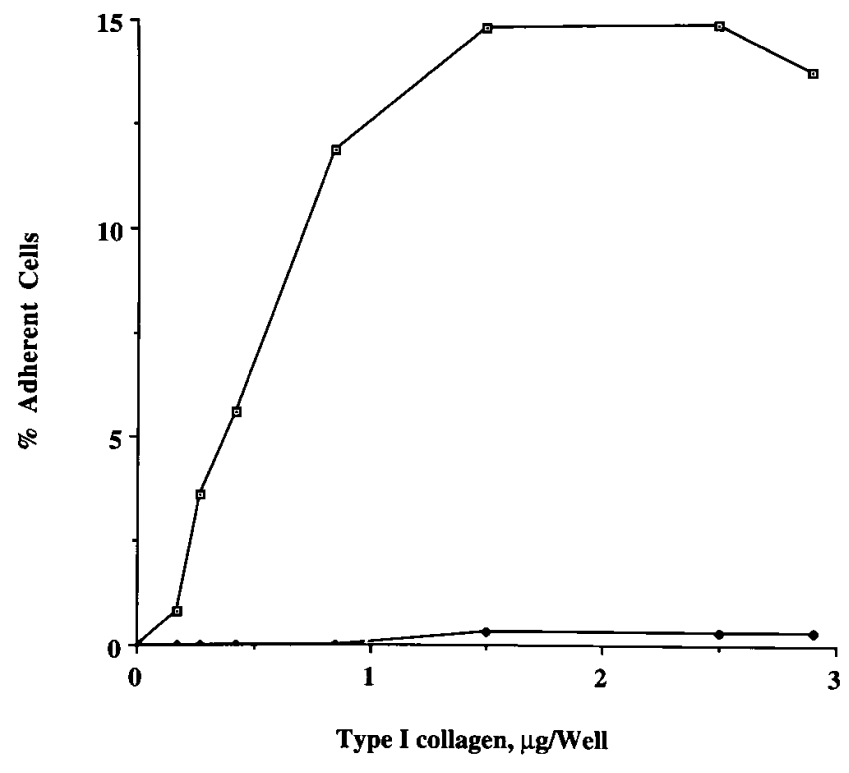

Figure 6. Binding of pcDNA3-65 cDNA-transfected cells to microtiter wells coated with varying concentrations of type I collagen. Microtiter wells were coated with various amounts of type I collagen ( 0 , $0.17,0.27,0.42,0.85,1.5,2.5$, and $2.9 \mu \mathrm{g} /$ well $)$ in phosphate buffer at $4^{\circ} \mathrm{C}$ overnight and blocked with $100 \mu \mathrm{g} / \mathrm{ml}$ BSA in PBS for $1 \mathrm{~h}$. The wells were then washed with PBS and $100 \mu \mathrm{l}$ of ${ }^{51} \mathrm{Cr}$-labeled, transfected cells $(1,400 \mathrm{cpm})(\square-\square)$ or control (vector-transfected) cells $(1,370 \mathrm{cpm})(\diamond)$ were added and then incubated at $37^{\circ} \mathrm{C}$ for 30 $\mathrm{min}$. At the end of incubation, the wells were washed five times with PBS, and the adherent cells were detached with two aliquots of $100 \mu \mathrm{l}$ of $5 \%$ SDS. The radioactivity in each sample was assessed in a scintillation counter in the presence of $10 \mathrm{ml}$ ScintiVerse BD. Data are shown as mean of duplicate experiments.

negative control, lane 1) nor the nonadherent cells (lane 2) expressed the anti-65m-reactive protein. These data suggest that the adherence of the positively transfected cell population is the result of interaction between the receptor for type I collagen on the cell membrane and the type I collagen immobilized on the plate.

The effect of the coating concentration of type I collagen on the binding of transfected cells was investigated next. Microtiter wells were coated with varying concentrations of type I collagen, and ${ }^{51} \mathrm{Cr}$-labeled pcDNA3-65 cDNA-transfected cells $(\square-\square)$ or control (vector-transfected) cells $(\bullet-\downarrow)$ were incubated for $30 \mathrm{~min}$ at $37^{\circ} \mathrm{C}$. As shown in Fig. 6, the binding of pcDNA3-65 cDNA-transfected cells was collagen concentration-dependent. Control (vector-transfected) cells did not bind to type I collagen-coated microtiter wells. Furthermore, the binding of the labeled transfected cells to type I collagencoated microtiter wells was inhibited by the addition of anti$65 \mathrm{~m}$ in a dose-dependent manner (Table III). By contrast, anti-47p had no effect on binding of the transfected cells to type I-coated microtiter wells. Finally, there was no detectable binding of the transfected cells on type III collagen-coated microtiter wells, or on fibronectin-coated microtiter wells (data not shown). These data indicate that the expression of the 65$\mathrm{kD}$ recombinant protein on nonadherent eukaryotic cells renders them adherent to type I collagen specifically, supporting the importance of the $65-\mathrm{kD}$ protein in interaction with type I collagen.
Table III. Binding of pcDNA3-65 cDNA-transfected CEM Cells to Type I Collagen-coated Petri Dishes and the Effect of anti-65m and anti-47p

\begin{tabular}{ccc}
\hline $\mathrm{IgG}$ & \multicolumn{2}{c}{ Bound $\left[{ }^{51} \mathrm{Cr}\right]-\mathrm{CEM}$ cells $(\mathrm{cpm} \pm \mathrm{SD})$} \\
\hline$\mu g$ & Anti-65m & Anti-47p \\
0 & $1085 \pm 113$ & $1085 \pm 113$ \\
1 & $670 \pm 38$ & $1032 \pm 8$ \\
5 & $370 \pm 43$ & $1062 \pm 21$ \\
10 & $224 \pm 24$ & $1014 \pm 35$ \\
20 & $254 \pm 13$ & $1024 \pm 24$ \\
\hline
\end{tabular}

Aliquots of the $\left[{ }^{51} \mathrm{Cr}\right]-\mathrm{CEM}$ cells $(12,391 \mathrm{cpm})$ were incubated with various amounts of $\mathrm{IgG}$ for $30 \mathrm{~min}$ at room temperature. At the end of incubation, cells were transferred to microtiter wells that were coated with type I collagen and incubated for another $30 \mathrm{~min}$. The free $\left[{ }^{51} \mathrm{Cr}\right]$-cells were aspirated, and the microtiter wells were washed six times with PBS $\left(150 \mu \mathrm{l}\right.$ each). The attached $\left[{ }^{51} \mathrm{Cr}\right]$-cells were solubilized with $50 \mu \mathrm{l}$ of $2 \%$ SDS three times. The radioactivity in the solubilized material was assessed by gamma counting. Data are expressed as mean \pm SD of triplicate experiments without subtracting background count (135 cpm).

Effects of the purified recombinant protein on platelet function. Previous studies showed that the $65-\mathrm{kD}$ protein isolated and purified from platelets could competitively inhibit type I collagen-mediated platelet aggregation, and the release of ATP (13). We therefore tested the effect of the purified recombinant protein on type I collagen-induced platelet aggregation, and the release of ATP. As shown in Fig. 7 (top), both platelet aggregation and the release of ATP were inhibited after preincubation of the recombinant protein with type I collagen in a dose-dependent manner. The degree of inhibition by $5 \mu \mathrm{g}$ of the recombinant protein in the assay (curves $C$ and $c$ for aggregation and the release of ATP, respectively) was $70 \%$, whereas $100 \%$ inhibition was attained by adding $10 \mu \mathrm{g}$ of the recombinant protein (curves $D$ and $d$ for aggregation and the release of ATP, respectively) compared to collagen alone (curves $B$ and $b$ for aggregation and the release of ATP). Buffer control is shown in curves $A$ and $a$ where no aggregation (curve $A$ ) or release of ATP (curve $a$ ) was obtained.

The inhibitory effect of the recombinant protein could be overcome by increasing the dose of type I collagen used to stimulate platelets. As shown in Fig. 7 (bottom), $10 \mu \mathrm{g}$ of the recombinant protein (curve $B$ and $b$, first arrow) clearly inhibits both platelet aggregation and the release of ATP induced by $0.5 \mu \mathrm{g}$ type I collagen. At the second arrow, an additional dose of $0.5 \mu \mathrm{g}$ type I collagen was added, and platelet aggregation was restored (Fig. 7, bottom, curve $B$ ) but the release of ATP (curve $b$ ) was only partially restored.

Increasing the amount of recombinant protein to $20 \mu \mathrm{g}$, as may be expected, inhibited the platelet aggregation and the release of ATP mediated by $0.5 \mu \mathrm{g}$ type I collagen (Fig. 7, bottom, curves $C$ and $c$ for aggregation and the release of ATP, respectively; first arrow). The addition of another $0.5 \mu \mathrm{g}$ type I collagen could not reverse the inhibition (Fig. 7, bottom, curves $C$ and $c$ for aggregation and the release of ATP, respectively; second arrow). At the end of the experiment (curve $C$, third arrow) an aliquot of $4 \mu \mathrm{M}$ ADP was added to the same cuvette. Both platelet aggregation and the release of ATP 


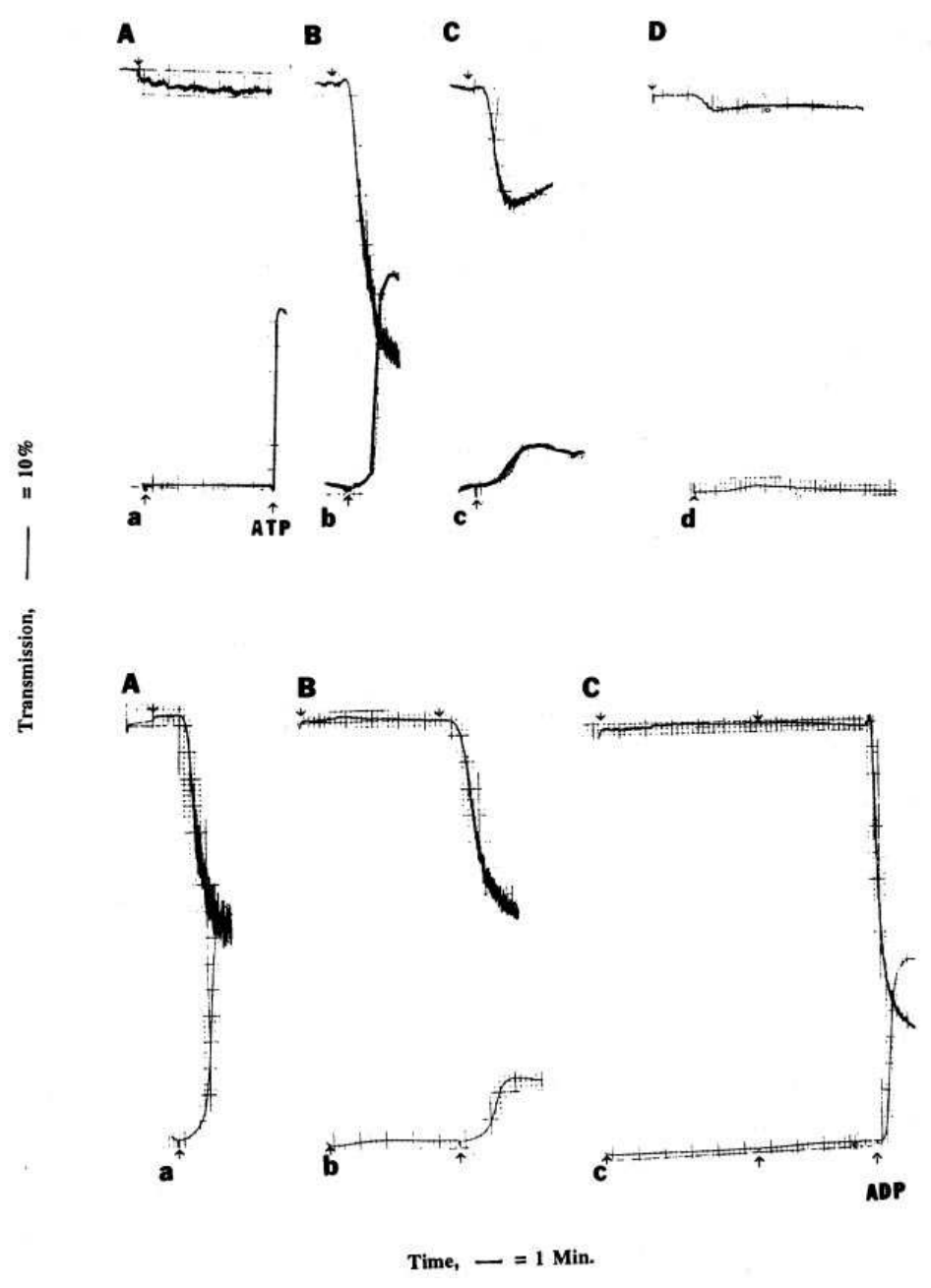

Figure 7. Effect of recombinant protein on type I collagen-induced platelet aggregation and the release of ATP. (Top) The effect of recombinant protein on type I collagen-induced platelet aggregation and the release of ATP. Type I collagen $(0.4 \mu \mathrm{g})$ was preincubated with various amounts of the recombinant protein for $10 \mathrm{~min}$ in aggregation cuvettes. Each incubated sample was added to PRP $(0.45 \mathrm{ml})$ and luciferin luciferase $(25 \mu \mathrm{l})$. A reduction in transmission $(A-D)$ and an increase in luminescence due to the release of ATP $(a-d)$ were recorded as shown in the figure. $A$ and $a$ are the aggregation and the release of ATP by the vehicle control, respectively. At the end of the experiment, ATP $(1 \mu \mathrm{M})$ was added to the cuvette to calibrate the luminescence increase. $B$ and $b$ are $0.4 \mu \mathrm{g}$ type I collagen-induced aggregation and release of ATP, respectively. $C$ and $c$ are tracing for $0.4 \mu \mathrm{g}$ collagen $+5 \mu \mathrm{g}$ recombinant protein. $D$ and $d$ are $0.4 \mu \mathrm{g}$ collagen $+10 \mu \mathrm{g}$ recombinant protein. (Bottom) The inhibitory effect of recombinant protein can be overcome by increased concentrations of type I collagen. $A$ and $a$ represent $0.5 \mu \mathrm{g}$ type I collagen-induced platelet aggregation and the release of ATP, respectively. $B$ and $b$ represent platelet aggregation and the release of ATP by the addition of the recombinant protein $(10 \mu \mathrm{g})$ and type I collagen $(0.5$ $\mu \mathrm{g}$ at the first arrow). At the second arrow, an additional dose of $0.5 \mu \mathrm{g}$ type I collagen was added. $C$ and $c$ are platelet aggregation, and the release of ATP by the addition of $20 \mu \mathrm{g}$ of the recombinant protein and type I collagen $(0.5 \mu \mathrm{g}$ at the first arrow $)$. At the second arrow, another $0.5 \mu \mathrm{g}$ of type I collagen was added. At the end of the experiment, $4 \mu \mathrm{M}$ ADP was added to test the response of platelets.

were observed, suggesting that the platelet was not damaged by the addition of the recombinant protein.

\section{Discussion}

We have cloned a 1.6-kb cDNA with a functional open reading frame from the human bone marrow cDNA library using two degenerate oligonucleotide probes designed from the amino acid sequence of a $\mathrm{CNBr}$ fragment $\left(25 \mathrm{kD} M_{\mathrm{r}}\right)$ of a platelet nonintegrin type I collagen receptor $\left(65 \mathrm{kD} M_{\mathrm{r}}\right)$. This cDNA was subcloned into a prokaryotic expression vector ( $\mathrm{pKK}$ 223-3), and a recombinant protein was expressed and purified to apparent homogeneity as shown on $7.5 \%$ SDS-PAGE. This recombinant protein is $54 \mathrm{kD} M_{\mathrm{r}}$, and it is recognized by anti$65 \mathrm{~m}$ specific for the platelet type I collagen receptor by Western blot analysis. The observed $M_{\mathrm{r}}$ of the prokaryotic recombinant protein is smaller than the platelet receptor protein that has a $65 \mathrm{kD} M_{\mathrm{r}}$. To investigate whether the difference could be attributed to glycosylation, two sets of experiments were carried out. When the $65-\mathrm{kD}$ protein isolated from platelet membranes is treated with endoglycosidase $\mathrm{H}$, the protein was reduced to $54 \mathrm{kD} M_{\mathrm{r}}$. The $54-\mathrm{kD}$ protein is not stained by periodic acid Schiff stain. In a eukaryotic expression vector, a recombinant protein was expressed in $\mathrm{CHO}$ cells with a $65 \mathrm{kD}$ $M_{\mathrm{r}}$. These data suggest that the receptor has a $54 \mathrm{kD} M_{\mathrm{r}}$ and is posttranslationally modified by glycosylation. The glycosylation of this protein does not seem to affect the function of the protein, since both the recombinant protein and the purified platelet protein inhibit type I collagen-induced platelet aggregation.

Type I collagen-induced platelet aggregation and the release of ATP were both inhibited by preincubation of the recombinant protein and collagen in a dose-dependent manner. Preincubation of platelets with the recombinant protein did not inhibit type I collagen-induced platelet aggregation or the release of ATP. This effect was observed when the recombinant protein was preincubated with type I collagen, suggesting that the recombinant protein binds to collagen.

Binding of pcDNA3-65 cDNA-transfected T cells to type I collagen-coated microtiter wells is type I collagen-dose-dependent. Importantly, the transfected cells did not bind to type III collagen-coated microtiter wells, suggesting that the $65-\mathrm{kD}$ protein plays a role in cell adhesion, specifically for type I collagen.

Although chick type I collagen was used in our initial work on the isolation of the $65-\mathrm{kD}$ receptor protein, we have subsequently found that the same results are obtained by using type I collagen from other mammalian species, including humans. For example, the binding of the recombinant protein to the type I collagen-Sepharose 2B column (Fig. 4), the adhesion of 
cDNA-transfected CEM cells to collagen-coated wells (Fig. 5), and the platelet aggregation studies (Fig. 7) were performed using human collagens prepared by us. Comparable results are obtained by using Chrono-Log Corp. collagen, or rat type I collagen. It would appear, therefore, that the specific structural elements of collagen involved in interaction with $65-\mathrm{kD}$ platelet receptor protein are common to type I collagen from various species.

Taken together, our current data suggest that the recombinant protein encoded by the $1.6-\mathrm{kb}$ cloned cDNA is a nonintegrin platelet receptor for type I collagen. This postulation is based on five supporting data. First, the recombinant protein is recognized by the monoclonal antibody raised against the platelet-purified $65-\mathrm{kD}$ protein. Second, the purified recombinant protein inhibits type I collagen-induced platelet aggregation and the release of ATP in a dose-dependent manner. Third, the inhibitory effect of the recombinant protein on platelet aggregation and the release of ATP requires the preincubation of the recombinant protein with collagen. Fourth, the binding of the recombinant protein to type I collagen-coated Petri dishes is inhibited by anti- $65 \mathrm{~m}$ but not anti-47p in a dosedependent manner. And finally, the binding of the transfected $\left[{ }^{51} \mathrm{Cr}\right]$-cells to type I collagen-coated microtiter wells is inhibited in a dose-dependent manner by the addition of anti- $65 \mathrm{~m}$.

Although our data presented in this paper clearly indicate that the $65-\mathrm{kD}$ protein serves as platelet receptor for type I collagen, it does not exclude the possibility that other platelet surface proteins (1-19) may also play a role in collagen-platelet interaction. Moreover, the relationship between the cloned receptor described here and other nonintegrin receptors described by others is not known. A search of gene and protein databases did not find a matching sequence, suggesting that the $65-\mathrm{kD}$ protein is a novel protein. More studies will be needed to clarify the complexities involved in collagen-platelet interaction.

\section{Acknowledgments}

We wish to thank Ms. V. Rasberry, Mr. J. West, and Mr. K. Alderick for their expert technical assistance. fairs.

This research was supported by the Department of Veterans Af-

\section{References}

1. Staatz, W.D., S.M. Rajpara, E.A. Wagner, W.G. Carter, and S.A. Santoro. 1989. The membrane glycoprotein Ia-IIa (VLA-2) complex mediates the $\mathrm{Mg}^{2+}$-dependent adhesion of platelets to collagen. J. Cell Biol. 108:1017-1024.

2. Staatz, W.D., J.J. Walsh, T. Pexton, and S.A. Santoro. 1990. The $\alpha 2 \beta 1$ integrin cell surface collagen receptor binds to the $\alpha 1$ (I)-CB3 peptide of collagen. J. Biol. Chem. 265:4778-4781.

3. Kotite, N.J., S.A. Santoro, and L.W. Cunningham. 1984. Interaction of specific platelet membrane proteins with collagen: evidence from chemical cross-linking. Biochemistry. 23:3099-3104.

4. Coller, B.S., J.H. Beer, L.E. Scudder, and M.H. Steinberg. 1989. Collagen-platelet interaction: evidence for a direct interaction of collagen with platelet GPIa/IIa and indirect interaction with platelet GPIIb/IIIa mediated by adhesive proteins. Blood. 74:182-192.

5. Booth, W.J., R.K. Andrew, P.A. Castaldi, and M.C. Berndt. 1990. The interaction of von Willebrand factor and the platelet glycoprotein Ib-IX complex. Platelets (Edinburgh). 1:169-176.
6. Lopez, J.A. 1994. The platelet glycoprotein Ib-IX complex. Blood Coag. Fibrinolysis. 5:97-119.

7. Tandon, N.N., U. Kralisz, and G.A. Jameison. 1989. Identification of glycoprotein IV (CD 36) as a primary receptor for platelet-collagen adhesion. $J$. Biol. Chem. 264:7576-7583.

8. Kotite, N.J., and L.W. Cunningham. 1986. Specific adsorption of a platelet membrane glycoprotein by human insoluble collagen. J. Biol. Chem. 261: 8342-8347.

9. Ryo, R., A. Yeshiva, W. Sugano, M. Yasunaga, K. Nakayama, K. Saigo, M. Adachi, N. Yamaguchi, and M. Okuma. 1992. Deficiency of P62, a putative collagen receptor, in platelets from a patient with defective collagen-induced platelet aggregation. Am. J. Hematol. 39:25-31.

10. Chiang, T.M., and A.H. Kang. 1982. Isolation and purification of collagen $\alpha 1(\mathrm{I})$ receptor from human platelet membranes. J. Biol. Chem. 257:75817586.

11. Barber, A.J., and G.A. Jameison. 1971. Platelet collagen adhesion characterization of collagen glucosyl transferase of plasma membranes of human blood platelets. Biochim. Biophys. Acta. 252:533-545.

12. Bensusan, H.B., T.L. Koh, K.G. Henry, B.A. Murray, and L.A. Culp. 1978. Evidence that fibronectin is the collagen receptor on platelet membranes. Proc. Natl. Acad. Sci. USA. 75:5864-5868.

13. Shadle, P.J., M.H. Ginsberg, E.F. Plow, and H. Barondes. 1984. Plateletcollagen adhesion: inhibition by a monoclonal antibody that binds glycoprotein IIb. J. Cell Biol. 99:2056-2060.

14. Aihara, M., H.A. Cooper, and R.H. Wagner. 1984. Platelet-collagen interactions: increase in rate of adhesion of fixed washed platelets by factor VIIIrelated antigen. Blood. 63:495-501.

15. Saito, Y., T. Imada, J. Takagi, T. Kikuchi, and Y. Inada. 1986. Platelet factor XIII. The collagen receptor? J. Biol. Chem. 261:1355-1358.

16. Lahav, J. 1987. Identification of a surface protein of the rabbit blood platelets with high affinity for collagen. Exp. Cell. Res. 168:447-456.

17. Takada, Y., and M.E. Helmer. 1989. The primary structure of the VLA2/collagen receptor $\alpha 2$ subunit (platelet GPIa): homology to other integrins and the presence of a possible collagen-binding domain. J. Cell Biol. 109: 397-407.

18. Moroi, M., S.M. Jung, M. Okuma, and K. Shinmyozu. 1989. A patient with platelets deficient in glycoprotein VI that lack both collagen-induced aggregation and adhesion. J. Clin. Invest. 84:1440-1445.

19. Deckmyn, E., E. von Houtte, and J. Vermylen. 1992. Disturbed platelet aggregation to collagen associated with an antibody against an $85 / 90 \mathrm{kD}$ platelet glycoprotein in a patient with prolonged bleeding time. Blood. 79:14661471.

20. Lammeli, U.K. 1970. Cleavage of structural proteins during the assembly of the head of bacteriophage T4. Nature (Lond.). 277:680-682.

21. Matsudaira, P. 1987. Sequence from picomole quantities of proteins electroblotted onto polyvinylidene difluoride membranes. J. Biol. Chem. 262: 10035-10038.

22. Lathe, R. 1985. Synthetic oligonucleotide probes deduced from amino acid sequence data: theoretical and practical considerations. J. Mol. Biol. 183:112.

23. Chiang, T.M., A. Jin, and A.H. Kang. 1987. Platelet-collagen interaction: inhibition by a monoclonal antibody raised against collagen receptor. $J$. Immunol. 139:887-892.

24. Chiang, T.M., A.H. Kang, J.M. Dale, and E.H. Beachey. 1984. Immunological studies of the purified human platelet receptor for the $\alpha 1(\mathrm{I})$-chain of chick skin collagen. J. Immunol. 133:872-876.

25. Towbin, H., T. Steahlin, and J. Gordon. 1979. Electrophoretic transfer of proteins from polyacrylamide gels to nitrocellulose sheets. Proc. Natl. Acad. Sci. USA. 71:4350-4354.

26. Lowry, O.H., H.J. Rosebrough, A.L. Farr, and R.J. Randall. 1951. Protein measurement with the Folin phenol reagent. J. Biol. Chem. 193:265-275.

27. Chiang, T.M., E.H. Beachey, and A.H. Kang. 1976. Interaction of a chick skin collagen fragment ( $\alpha 1$-CB5) with human platelets. Biochemical studies during the aggregation and release reaction. J. Biol. Chem. 257:7581-7586.

28. Born, G.V.R. 1962. Aggregation of platelets by adenosine diphosphate and its reversal. Nature (Lond.). 194:927-929.

29. Kang, A.H., K.A. Piez, and J. Gross. 1969. Characterization of the $\alpha$ chain of chick skin collagen and the nature of the NH2-terminal cross link region. Biochemistry. 8:3648-3655.

30. Sanderson, A.R. 1964. Applications of iso-immune cytosis using radiolabeled target cells. Nature (Lond.). 204:250-254.

31. Wigzell, H. 1965. Quantitative titration of mouse immunocytosis using $\mathrm{Cr}^{51}$ labeled target cells. Transplantation. 3:423-429.

32. Chiang, T.M., J.M. Seyer, and A.H. Kang. 1993. Collagen-platelet interaction: separate receptor sites for types I and III collagen. Thromb. Res. 71:443456. 